\title{
DNA Barcode of Seven Indonesian Hornbills Species (Aves: Bucerotidae) Based on Mitochondrial DNA Cytochrome Oxidase Subunit I
}

\author{
Jarulis ${ }^{1}$, Dedy Duryadi Solihin ${ }^{2 *}$, Ani Mardiastuti ${ }^{3}$, Lilik Budi Prasetyo ${ }^{3}$ \\ ${ }^{1}$ Department of Biology, Faculty of Mathematics and Natural Sciences, University of Bengkulu, Bengkulu, Indonesia \\ ${ }^{2}$ Department of Biology, Faculty of Mathematics and Natural Sciences, Bogor Agricultural University, Bogor, Indonesia \\ ${ }^{3}$ Department of Ecotourism and Biodiversity Conservation, Faculty of Forestry, Bogor Agricultural University, Bogor, Indonesia
}

\section{ARTICLE INFO}

\section{Article history:}

Received June 7, 2018

Received in revised form September 15, 2018

Accepted September 30, 2018

\section{KEYWORDS:}

hornbills,

COI gene,

DNA barcode,

genetic distance,

phylogenetic

\begin{abstract}
DNA barcoding based on mitochondrial DNA COI gene is very useful in identifying of Indonesian hornbill. We sequenced the DNA barcode of seven hornbill species using the mitochondrial DNA COI gene to explore their genetic variation, identity, distance, and phylogenetic. Thirty-one blood samples from seven hornbill species were isolated and analyzed. Slight variation was observed within the nucleotide of the hornbill species. In contrary, fairly significant difference was shown within the genus and family level. COI gene sequences generated from this study, showed unmatched result with BoLD System database. These seven Indonesian hornbill species were then divided into two groups, namely Group I consisting of Aceros cassidix, Rhyticeros plicatus, R. undulatus, Buceros rhinoceros, and B. bicornis, while Group II occupied by Anthracoceros albirostris and A. malayanus; both groups with genetic distance $\mathbf{5 . 9 0 \%}$. Overall in-group had $\mathbf{9 . 4 0 \%}$ distances to the hornbill used as the out group. COI sequence gene from these seven hornbill species are novel for identifying Indonesian hornbills. We encourage its use as quick species identification, applied to prevent illegal poaching conservation management.
\end{abstract}

\section{Introduction}

Hornbills (Aves: Bucerotidae) are group of large birds, with dominant body color of black and white; some species have casque on their beak, and dieting mostly on fruits and insects (Poonswad et al. 1998; MacKinnon et al. 2010; Poonswad et al. 2013; Eaton et al. 2016). They play an important role as seed dispersers in the forest (Kinnaird 1998; Kitamura et al. 2008; Balasubramanian et al. 2011). They are able to disperse of exotic plant seed (Viseshakul et al. 2011). There are 13 species of hornbills in Indonesia and all is protected by law (Sukmantoro et al. 2007).

As the clear identity for hornbill genus and some of its species are not yet available, resulting in the variety of names used to address the hornbill genus and its species (MacKinnon et al. 1998; Coates et al. 2000; Sukmantoro et al. 2007; MacKinnon et al. 2010; Poonswad et al. 2013; Eaton et al. 2016); while

\footnotetext{
* Corresponding Author

E-mail Address: dduryadi@yahoo.com

taxonomically, some species are still reluctantly categorized as sub species, such as Rhinoceros Hornbill Buceros rhinoceros, Oriental Pied Hornbill Anthracoceros albirostris, Knobbed Hornbill Aceros cassidix, Sulawesi Hornbill Penelopides exarhatus, and Blyth's Hornbill Rhyticeros plicatus (Coates et al. 2000; MacKinnon et al. 2010; Poonswad et al. 2013; Eaton et al. 2016). The genus and species determination are still based on mere morphological characters such as body color and body parameters. While species identification using morphological characters can be accurate for some species with sufficient records, however, it brings confusion when identification is done for species with no specific morphological characters. The molecular technic offers solution for this problem, by using reliable molecular marker for animal barcoding, which is the cytochrome oxidase sub-unit I (COI) from mitochondrial DNA (Hebert et al. 2003b, 2004; Hajibabaei et al. 2006).

The cytochrome oxidase sub-unit I gene of mitochondrial DNA (hereinafter COI gene) is a steady gene used for DNA barcoding. Mitochondrial DNA, 
with no recombination and high mutation rate during its maternal inheritance and much higher than that of the nuclear DNA, fulfills most requirements as molecular marker at the inter species level of vertebrate (Brown et al. 1982; Avise 1994). It is also a valuable and powerful tool for identifying molecular samples from threatened or endangered species (Palumbi and Cipriano 1998). The COI gene has been used to determine the identity of certain species (Solihin 1994) and has become satisfied genetic marker for vertebrate animal barcoding DNA with its 648 bp of nucleotide sequence length (Hebert et al. 2004). DNA barcoding has great contribution in taxonomic, population genetics, diversity; as well become tool in the research on level of variation among species and phylogenetic study (Hajibabaei et al. 2007; Imtiaz et al. 2017). Currently, there is no COI gene for Indonesian hornbills available and this study provides the first batch of DNA barcodes for some Indonesian hornbill species.

This study aimed to determine the genetic variation within and among Indonesian hornbill species to clarify their relationship; as well as to seek the potential use for future barcoding. The sequence of nucleotides generated from this study can be used to identify hornbills species genetically, using even small amount of DNA source samples, such as molted feathers, beaks, and other body parts.

\section{Materials and Methods}

\subsection{Sample Collection}

The research had been conducted from July 2016 to December 2017. Blood sample were collected from 31 individuals of seven hornbill species, which separatedly reared in Taman Mini Indonesia Indah (TMII) Jakarta, Taman Safari Indonesia (TSI) Cisarua Bogor, and Taman Margasatwa Ragunan (TMR) Jakarta (Table 1). As much as $0.3-1.0 \mathrm{ml}$ of blood were micro-piped through the carpal joints vein, guided by the ethical approval of Bogor Agricultural University Animal Ethic Commission number 392106 IPB 2016. Bloods preserved following Seutin et al. (1991). Molecular analysis was then carried out in the Laboratory of Molecular Biology, Research Center for Biological Resources and Biotechnology

Table 1. Number of samples used for analysis

\begin{tabular}{|c|c|c|c|c|c|}
\hline Species & English name & $n$ & Sample code & Ring/microchip code & Location \\
\hline Anthracoceros malayanus & Black Hornbill & 4 & AM1RG & 985121018348577 & TMR \\
\hline A. malayanus & Black Hornbill & & AM2RG & 985121018311231 & TMR \\
\hline A. malayanus & Black Hornbill & & AM1TM & TMII12048 & TMII \\
\hline A. malayanus & Black Hornbill & & AM1TS & TSIBGR12G 038 & TSI \\
\hline Anthracoceros albirostris & Oriental Pied Hornbill & 6 & AA1RG & 985121018247394 & TMR \\
\hline A. albirostris & Oriental Pied Hornbill & & AA1TM & TMIIK 12013 & TMII \\
\hline A. albirostris & Oriental Pied Hornbill & & AA2TM & K12046 & TMII \\
\hline A. albirostris & Oriental Pied Hornbill & & AАЗТМ & K12047 & TMII \\
\hline A. albirostris & Oriental Pied Hornbill & & AA5TS & TSIBGR12G 016 & TSI \\
\hline A. albirostris. & Oriental Pied Hornbill & & AA11TS & TSIBGR12G 018 & TSI \\
\hline Aceros cassidix & Knobbed Hornbill & 3 & AC1RG & 985121018260062 & TMR \\
\hline A. cassidix & Knobbed Hornbill & & AC1TS & TSIBGR17G 047 & TSI \\
\hline A. cassidix & Knobbed Hornbill & & AC2TS & TSIBGR17G 046 & TSI \\
\hline Rhyticeros plicatus & Blyth's Hornbill & 5 & RP1RG & 985121018304960 & TMR \\
\hline R. plicatus & Blyth's Hornbill & & RP1TM & N365 & TMII \\
\hline R. plicatus & Blyth's Hornbill & & RP2TM & 213 & TMII \\
\hline R. plicatus & Blyth's Hornbill & & RP1TS & TSIBGR14G 048 & TSI \\
\hline R. plicatus & Blyth's Hornbill & & RP3TS & TSIBGR17G 065 & TSI \\
\hline Rhyticeros undulatus & Wreathed Hornbill & 8 & RU1TM & I113 & TMII \\
\hline R. undulatus & Wreathed Hornbill & & RU2TM & N312 & TMII \\
\hline R. undulatus & Wreathed Hornbill & & RU3TM & N325 & TMII \\
\hline R. undulatus & Wreathed Hornbill & & RU4TM & 242 & TMII \\
\hline R. undulatus & Wreathed Hornbill & & RU5TM & N346 & TMII \\
\hline R. undulatus & Wreathed Hornbill & & RU6TM & N298 & TMII \\
\hline R. undulatus & Wreathed Hornbill & & RU7TM & ZTMII115 & TMII \\
\hline R. undulatus & Wreathed Hornbill & & RU5TS & TSIBGR17G 061 & TSI \\
\hline Buceros rhinoceros & Rhinoceros Hornbill & 4 & BR1TM & N324 & TMII \\
\hline B. rhinoceros & Rhinoceros Hornbill & & BR2TM & N300 & TMII \\
\hline B.rhinoceros & Rhinoceros Hornbill & & BR1RG & 985121018297670 & TMR \\
\hline B. rhinoceros & Rhinoceros Hornbill & & BR2TS & TSIBGR17G 044 & TSI \\
\hline Buceros bicornis & Great Hornbill & 1 & BB1RG & 985121018259627 & TMR \\
\hline Aceros waldeni & Rufous headed Hornbill & 1 & NC015085 & - & GenBank \\
\hline A. corrugatus & Wrinkled Hornbill & 1 & HM755883 & - & GenBank \\
\hline Penelopides panini & Visayan Tarictic Hornbill & 1 & NC015087 & - & GenBank \\
\hline Total of sample & & 34 & & & \\
\hline
\end{tabular}


(PPSHB), Bogor Agricultural University (IPB). Three COI gene sequences downloaded from GenBank were used as the out group (NC015085, HM755883, and NC015087).

\subsection{Isolation and Purification}

Blood sample from 31 individuals were preserved in $100 \%$ ethanol and freezing at $-20^{\circ} \mathrm{C}$. As much as $25 \mathrm{mg}$ of blood was put into the effendorf tube and washed by Tris-EDTA buffer (low TE). Genome DNA was isolated with Spin-Column Protocol, using DNeasy Tissue Kit ® Blood and paint No. 69504 (50) from Qiagen.

\subsection{PCR Amplification and Sequencing}

Weused polymerasechainreaction(PCR)technique to identify differences in the COI gene nucleotide sequences. Primer was designed using Primer3 software (http://bio-info.ut.ee/primer3-0.4.0/ primer3), where the alignment was based on the one of Rufous-headed Hornbill Aceros waldeni (accession no. NC015085). The primers were named as COIBuceF (5'-TCAACTAACCACAAAGACATCGGCAC-3') and COIBuceR (5'-ACGTGTGAGATAATTCCAAAGCCTG-3') and produced $746 \mathrm{bp}$ nucleotides. Amplification was performed in Rotor Gene-Q machine.

Reaction mixture consisted of $2 \mu \mathrm{l}$ DNA template, $1.0 \mu \mathrm{l}$ forward and reverse primer $(20 \mathrm{pmol} / \mu \mathrm{l})$, 6.8 $\mu$ l ddH2O, $5.0 \mu \mathrm{l}$ Qs buffer, $5.0 \mu$ l Enhancer, $1.0 \mu \mathrm{l}$ $\mathrm{dNTP}$, and $0.2 \mu \mathrm{l}$ Taq polymerase. The PCR performed temperature sequences as follow; $95^{\circ} \mathrm{C}$ of predenaturation ( 5 minutes), $94^{\circ} \mathrm{C}$ of denaturation (1 minute), annealing with $54^{\circ} \mathrm{C}$ (45 seconds), and extension at $72^{\circ} \mathrm{C}$ temperature (1 minutes). Amplified DNA were then migrated onto $1.2 \%$ agars gel (Sambrook 1989), before transported to First BASE laboratory in Malaysia for further sequencing.

\subsection{Data Analysis}

Nucleotides sequences were edited and aligned using Clustal W implemented in MEGA 6.0 software (Tamura et al. 2013). We used BIOEDIT version 7.0.9 (Hall 1999) for checking and trimming the sequences. The final alignment of each samples (746 bp) was then imported into Barcode of Life Database (BoLD) System in http://www.barcodinglife.org website to determine the similarity of the samples. Genetic distances were determined based on Kimura 2-parameter (K2P) method (Kimura 1980). We reconstructed phylogenetic tree using NeighborJoining ( $\mathrm{NJ}$ ) models with 1000 bootstrap repetition (Tamura et al. 2013).

\section{Results}

\subsection{Nucleotide Variation}

Variation, mutation type and basic composition from 31 individuals of the seven Indonesian hornbills species were summarized in Table 2. Final alignment amplified COI gene with Clustal $\mathrm{W}$ of MEGA 6 software resulting in total of $746 \mathrm{bp}$. The number of conservative sites on genus level ranged between 712 bp (95.44\%) and 737 bp (98.79\%), and on family was 638 bp (85.53\%). The variable sites for genera Aceros, Rhyticeros, Buceros, and Anthracoceros were as many as $9,16,17$, and 34 sites respectively. The variable sites for the whole sample (Bucerotidae family) were $108 \mathrm{bp}(14.47 \%)$.

The most number of singleton sites in genus level was observed on Buceros genus (17 bp) and the least was at Rhyticeros ( $5 \mathrm{bp}$ ). The most informative Parsimony site was in Anthracoceros genus (24 bp) and the lowest one on Aceros (0 bp). Number of transitional substitutions ( $21 \mathrm{bp}$ ) were greater than transversion substitutions (9 bp).

Table 2. Conserve and variable sites, types of mutations, and base composition of the Indonesian hornbills COI gene in 746 bp length

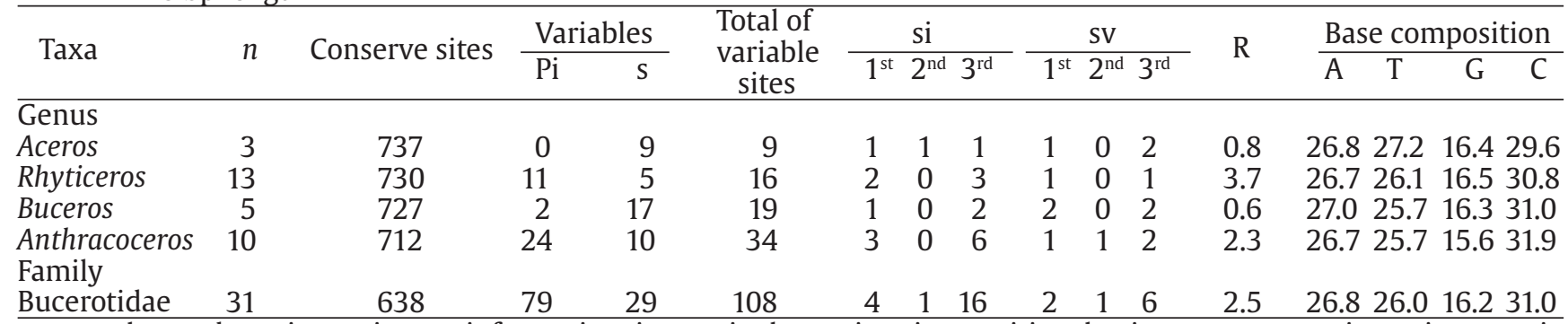
$\mathrm{n}=$ sample number, $\mathrm{pi}=$ parsimony-informative site, $\mathrm{s}=$ singleton site, $\mathrm{si}=$ transitional pairs, $\mathrm{sv}=$ transversion pairs, $\mathrm{r}=\mathrm{ratio}$ of si/sv 
Transition and transversion substitution occured at the third codon for both genus and family level. The ratio of transitional and transversional pairs values (R) ranged between 0.8 and 3.7 on genus level, and 2.5 on family level. Cytosine (C) became the most nucleotide in COI gene sequences composition and guanine $(\mathrm{G})$ was the lowest one. AT base composition for all samples were $52.8 \%$ and GC $47.2 \%$.

\subsection{Species Identification}

We presented similarity scores of 31 hornbill individuals examined with BoLD System in Table 3 where each individual paired with the three hornbills in out-group and ranked according to the degree of its similarity. We observed the three highest similarity score among paired individuals; the first ranged between $91.05 \%$ and $92.89 \%$, the

Table 3. Top three species identification result based on BoLD system database

\begin{tabular}{|c|c|c|c|c|c|c|c|}
\hline Species & $\begin{array}{l}\text { Sample } \\
\text { code }\end{array}$ & $\begin{array}{l}\text { Top three } \\
\text { species }\end{array}$ & Similarity (\%) & Species & $\begin{array}{l}\text { Sample } \\
\text { code }\end{array}$ & $\begin{array}{l}\text { Top three } \\
\text { species }\end{array}$ & Similarity (\%) \\
\hline \multirow{3}{*}{$\begin{array}{l}\text { Anthracoceros } \\
\text { malayanus }\end{array}$} & \multirow{3}{*}{ AM1RG } & P. panini & 91.51 & \multirow[t]{3}{*}{ B. rhinoceros } & \multirow[t]{3}{*}{ BR2TS } & P. panini & 91.67 \\
\hline & & A. coronatus & 90.69 & & & A. waldeni & 89.48 \\
\hline & & A. waldeni & 89.88 & & & A. coronatus & 89.34 \\
\hline \multirow[t]{3}{*}{ A. malayanus } & \multirow[t]{3}{*}{ AM2RG } & P. panini & 91.51 & Buceros & \multirow[t]{3}{*}{ BB1RG } & P. panini & 91.67 \\
\hline & & A. coronatus & 90.69 & bicornis & & A. waldeni & 90.03 \\
\hline & & A. waldeni & 90.15 & & & R. leucocephalus & 89.78 \\
\hline \multirow{3}{*}{ A. malayanus } & \multirow{3}{*}{ AM1TM } & P. panini & 91.67 & Rhyticeros & \multirow{3}{*}{ RU1TM } & P. panini & 92.58 \\
\hline & & A. coronatus & 90.69 & undulatus & & A. waldeni & 91.63 \\
\hline & & A. waldeni & 90.15 & & & R. corrugatus & 91.55 \\
\hline \multirow[t]{3}{*}{ A. malayanus } & \multirow[t]{3}{*}{ AM1TS } & P. panini & 91.05 & \multirow[t]{3}{*}{ R. undulatus } & \multirow[t]{3}{*}{ RU2TM } & P. panini & 92.58 \\
\hline & & A. coronatus & 90.28 & & & A. waldeni & 91.63 \\
\hline & & A. waldeni & 89.47 & & & R. corrugatus & 91.55 \\
\hline \multirow{3}{*}{$\begin{array}{l}\text { Anthracoceros } \\
\text { albirostris }\end{array}$} & \multirow{3}{*}{ AA1RG } & A. coronatus & 92.04 & \multirow[t]{3}{*}{ R. undulatus } & \multirow[t]{3}{*}{ RU3TM } & P. panini & 92.71 \\
\hline & & P. panini & 91.36 & & & A. waldeni & 91.77 \\
\hline & & R. corrugatus & 89.83 & & & R. corrugatus & 91.71 \\
\hline \multirow[t]{3}{*}{ A. albirostris } & \multirow[t]{3}{*}{ AA1TM } & A. coronatus & 92.04 & \multirow[t]{3}{*}{ R. undulatus } & RU4TM & P. panini & 92.75 \\
\hline & & P. panini & 91.36 & & & A. waldeni & 91.90 \\
\hline & & R. corrugatus & 89.83 & & & R. corrugatus & 91.55 \\
\hline A. albirostris & AA2TM & A. coronatus & 92.04 & R. undulatus & RU5TM & P. panini & 92.75 \\
\hline & & P. panini & 91.36 & & & A. waldeni & 91.90 \\
\hline & & R. corrugatus & 89.83 & & & R. corrugatus & 91.55 \\
\hline A. albirostris & AA3TM & A. coronatus & 91.90 & R. undulatus & RU6TM & P. panini & 92.71 \\
\hline & & P. panini & 91.23 & & & A. waldeni & 91.77 \\
\hline & & R. corrugatus & 89.83 & & & R. corrugatus & 91.71 \\
\hline A. albirostris & AA5TS & A. coronatus & 91.77 & R. undulatus & RU7TM & P. panini & 92.75 \\
\hline & & P. panini & 91.09 & & & A. waldeni & 91.90 \\
\hline & & A. waldeni & 89.74 & & & R. corrugatus & 91.77 \\
\hline A. albirostris & AA11TS & A. coronatus & 91.90 & R. undulatus & RU5TS & P. panini & 92.59 \\
\hline & & P. panini & 91.23 & & & A. waldeni & 91.77 \\
\hline & & R. corrugatus & 89.67 & & & R. corrugatus & 91.39 \\
\hline Aceros cassidix & AC1RG & P. panini & 92.56 & Rhyticeros & RP1RG & P. panini & 92.98 \\
\hline & & R. corrugatus & 91.67 & plicatus & & A. waldeni & 91.50 \\
\hline & & A. waldeni & 91.46 & & & R. corrugatus & 91.39 \\
\hline A. cassidix & AC1TS & P. panini & 92.75 & R. plicatus & RP1TM & P. panini & 92.71 \\
\hline & & R. corrugatus & 91.55 & & & A. waldeni & 91.23 \\
\hline & & A. waldeni & 91.36 & & & R. corrugatus & 91.08 \\
\hline A. cassidix & AC2TS & P. panini & 92.44 & R. plicatus & RP2TM & P. panini & 92.98 \\
\hline & & R. corrugatus & 91.24 & & & A. waldeni & 91.50 \\
\hline & & A. waldeni & 91.09 & & & R. corrugatus & 91.39 \\
\hline Buceros & BR1TM & P. panini & 91.94 & R. plicatus & RP1TS & P. panini & 92.85 \\
\hline rhinoceros & & A. waldeni & 89.75 & & & A. waldeni & 91.36 \\
\hline & & A. coronatus & 89.62 & & & R. corrugatus & 91.24 \\
\hline B. rhinoceros & BR2TM & P. panini & 92.08 & R. plicatus & RP3TS & P. panini & 92.85 \\
\hline & & A. waldeni & 89.89 & & & R. corrugatus & 91.55 \\
\hline & & A. coronatus & 89.75 & & & A. waldeni & 91.36 \\
\hline B. rhinoceros & BR1RG & P. panini & 92.08 & & & & \\
\hline & & A. waldeni & 89.89 & & & & \\
\hline & & A. coronatus & 89.75 & & & & \\
\hline
\end{tabular}

R. corrugatus $=$ Rhabdotorrhinus corrugatus, . leucocephalus $=$ Rhabdotorrhinus leucocephalus, A. coronatus $=$ Anthracoceros coronatus 
second ranged between $89.48 \%$ and $91.90 \%$, and the third between $89.34 \%$ and $91.77 \%$. Five hornbill species fell within those ranges, they are Penelopides panini, Aceros waldeni, A. coronatus, Rhabdotorrhinus (Aceros) corrugatus and $R$. leucocephalus.

\subsection{Single Nucleotide Polymorphism within Genus and Family}

This study detected variations of nucleotides within genus and family. Alignment result of COI gene sequence from 31 hornbill samples indicated 45 sites of single nucleotide polymorphism (SNP) within genus dan family species (Table 4) which located between 84 and 737 sites. Number of different sites between species (within genus) was ranged from 2-7 sites. The Anthracoceros malayanus has 7 distinguishing specific nucleotide sites with other species, positioned at site 108, 378, 537, 604, 642, 717, and 718. The A. albirostris has 5 different nucleotide specific sites with other species, located at site 373, 471, 597, 640, and 697. The Buceros rhinoceros has 2 specific nucleotide sites with other species, located at site 339 and 510.

The $B$. bicornis has 3 different specific nucleotide sites with other species, positioned at site 240, 241, and 579. The Aceros cassidix has 6 distinct specific nucleotide sites with other species, founded at site $84,90,219,303,603$, and 690 . The Rhyticeros undulatus and $R$. plicatus have only 2 and 3 different sites each (Table 4). We also found the different specific nucleotide site within family or between genera. Number of different specific nucleotide sites between genera was ranged from 0-10 sites. The Anthracoceros genus has 10 divergent sites with other genera, positioned at 222, 255, 261, 345, 453, 519, 594, 600, 615, and 712 sites. The Buceros genus has 5 divergent sites with other genera, and the Aceros genus has 6 different sites. However, Rhyticeros has no different site at genus level (Table 4).

\subsection{Genetic Distance}

Genetic distance within species, genus, and family of hornbills was measured using K2P methods (Table 5 and 6). Average genetic distance within species was ranged from $0.002(0.2 \%)$ to $0.008(0.8 \%)$, within genus 0.045 (4.5\%), and within family 0.046 (4.6\%) (Table 5).
The mean genetic distance within genus appears to vary (Table 6). Genetic distance between Rhyticeros undulatus and R. plicatus was 0.013 (1.3\%) and between Buceros rhinoceros and B. bicornis 0.016 (1.6\%). Interspecific genetic distance within two genera (Rhyticeros and Buceros) was lower than the threshold for species separation (> 3.0\%). Genetic distance within Bucerotidae family 0.046 (4.6\%), which is lower than what found in previous studies (Table 6).

\subsection{Phylogenetic}

We reconstructed phylogenetic tree using $\mathrm{NJ}$ models with 1000 bootstrap repetition (Figure 1). Three hornbill species were retrieved from GenBank (NCBI) as an out group. In the tree, Indonesian hornbills lumped into two main groups (clades) with bootstrap ranged from 54 to $100 \%$. Group I consisted of five species, namely Aceros cassidix, Rhyticeros plicatus, $R$. undulatus, Buceros rhinoceros, and $B$. bicornis with bootstrap value ranged from 54 to $99 \%$. Two members of Anthracoceros, A. malayanus and $A$. albirostris, formed separate Group II, with bootstrap $88-100 \%$. The two groups were supported by 0.059 (5.90\%) genetic distance. Indonesian hornbills clearly separated from hornbills in the out group, supported with 0.094 (9.40\%) genetic distance.

\section{Discussion}

Small nucleotide variation was found within species level, while fairly large difference was shown within genus and family level (Tabel 2). The length of the COI gene used for the barcode is around half of the total length located at beginning of the COI gene in all animal species (Pacheco et al. 2011; Sammler et al. 2011; Gonzales et al. 2013; Zhou et al. 2015). Very short barcode sequences (109-208 bp) are, nonetheless, also useful for species identification (Hajibabaei et al. 2006). In our research, the COI gene was successfully amplified into the length of $746 \mathrm{bp}$. It is longer than the one suggested for DNA barcode purpose (Hebert et al. 2004; Hajibabaei et al. 2006; Prehadi et al. 2015; Huang and Tu 2016). Nevertheless, it is shorter than Cockatoos (Psittaciformes) COI gene (807 bp) (Astuti and Sulandari 2010). 


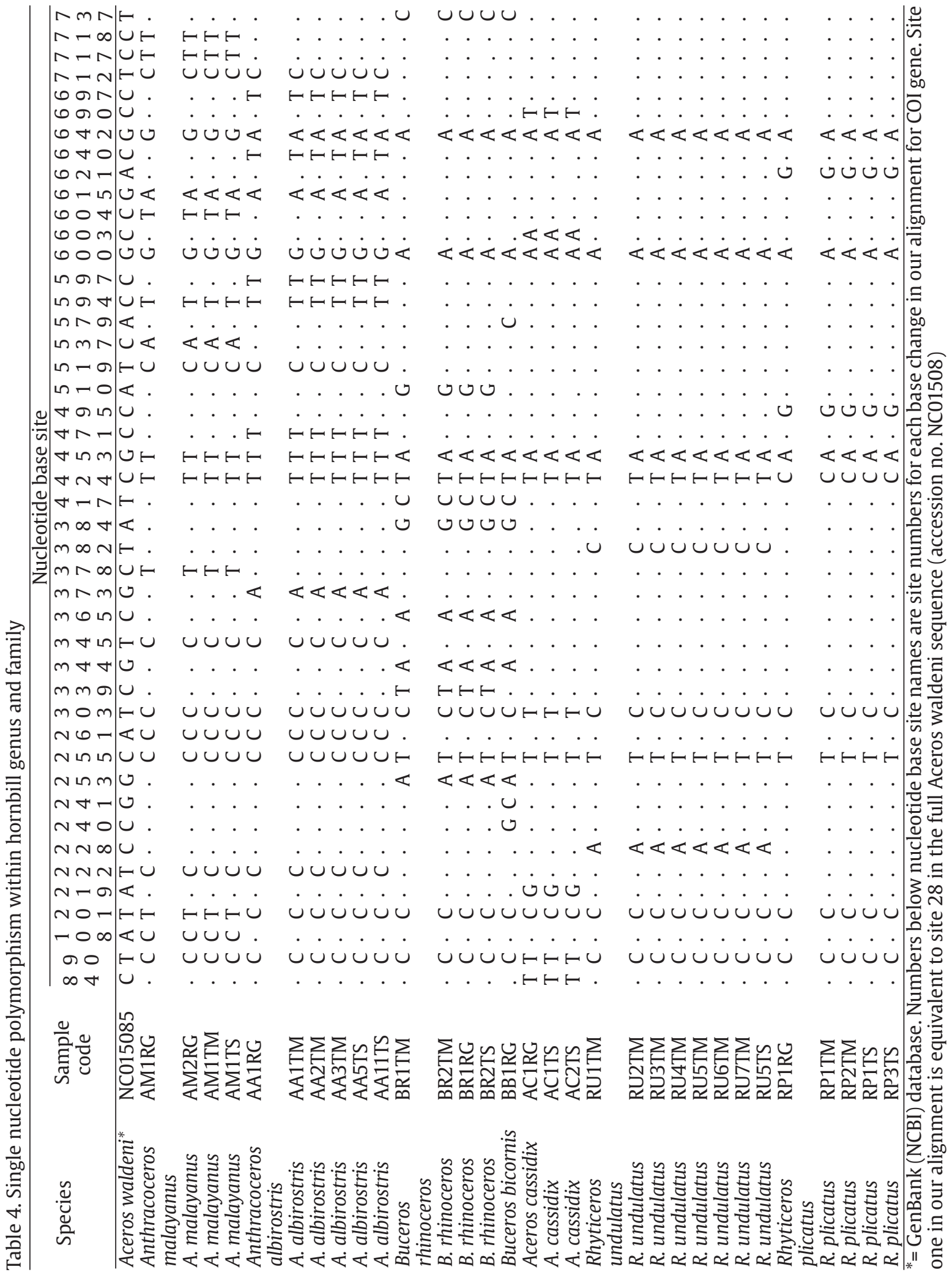


Table 5. Average genetic distance within species, genus, and family of hornbills based on partial COI gene in 746 length

\begin{tabular}{lccccccc}
\hline Genetic distance & A. malayanus & A. albirostris & B. bicornis & B. rhinoceros & R. undulatus & R. plicatus & A. cassidix \\
\hline Within species minimum & 0.001 & 0.000 & - & 0.001 & & 0.000 & 0.003 \\
Within species maximum & 0.011 & 0.007 & - & 0.011 & & 0.004 & 0.012 \\
Mean within species & 0.007 & 0.004 & - & 0.007 & & 0.002 & 0.008 \\
Within genus minimum & & & & & 0.013 & & \\
Within genus maximum & & & & & 0.066 & \\
Mean within genus & & & & & 0.028 & & \\
Within family minimum & & & & & 0.062 & & \\
Within family maximum & & & & & & 0.046 & \\
Mean within family & & &
\end{tabular}

Table 6. Genetic distance within genus of bucerotidae

\begin{tabular}{lcccccccccc}
\hline Species & 1 & 2 & 3 & 4 & 5 & 6 & 7 & 8 & 9 & 10 \\
\hline A. malayanus & & & & & & & & & & \\
A. albirostris & 0.032 & & & & & & & & \\
B. bicornis & 0.063 & 0.054 & & & & & & & \\
B. rhinoceros & 0.061 & 0.054 & 0.016 & & & & & & \\
R. undulatus & 0.065 & 0.055 & 0.036 & 0.041 & & & & & \\
R. plicatus & 0.063 & 0.052 & 0.033 & 0.038 & 0.013 & & & & \\
A. cassidix & 0.066 & 0.060 & 0.044 & 0.052 & 0.030 & 0.027 & & & \\
A. waldeni & 0.110 & 0.112 & 0.108 & 0.115 & 0.088 & 0.093 & 0.094 & & \\
A. corrugatus & 0.104 & 0.103 & 0.106 & 0.109 & 0.086 & 0.085 & 0.049 & 0.049 & \\
10. P. panini & 0.100 & 0.093 & 0.090 & 0.087 & 0.078 & 0.075 & 0.085 & 0.059 & 0.052 \\
\hline
\end{tabular}

We presented similarity scores of 31 hornbill individuals examined with BoLD System in Table 3 where each individual paired with the three hornbills in out-group and ranked according to the degree of its similarity. Five hornbill species fell within those ranges, they are Penelopides panini, Aceros waldeni, A. coronatus, Rhabdotorrhinus (Aceros) corrugatus, and $R$. leucocephalus. These species belong to the family of Bucerotidae order Bucerotiformes (Poonswad et al. 2013).

All tested individuals was having similarity values less than $97.0 \%$. This fact reflected the inavailability of nucleotide sequence of the COI genes of these seven hornbills species in BoLD System database. These hornbills had $7.11 \%$ difference to hornbill database in BoLD System. The difference here is considerably higher than the interspecific threshold among animal species (> 3.0\%) (Hebert et al. 2003a; Vilaça et al. 2006; Efe et al. 2009). Therefore, the COI gene nucleotide sequences studied is a new data and could be used as a reference in identifying of Indonesian hornbill.

This study identified variations of nucleotides within genus and family. Alignment result of COI gene sequence from 31 hornbill samples indicated 45 sites of single nucleotide polymorphism (SNP) within genus dan family species (Table 4) which located between 84 and 737 sites. At species level, we detected three hornbills (Anthracoceros malayanus, A. albirostris, and Aceros cassidix) with the highest variation, while the rest of the species lack with variation. At the genus level, the highest variation of COI gene was found in Anthracoceros (10 sites) and the lowest was at Buceros (5 sites). Variations in COI gene sequences can be used to distinguish closeallied species in all animal taxa which suggested that the diversity of mtDNA COI gene sequences in 648 bp areas may potentially function as animal species barcodes (Hebert et al. 2004), and each species has a specific nucleotide sequence in the COI gene (Waugh 2007). Genetic variation at the DNA level can be identified through modern molecular technology (Sutarno 2003).

Genetic distance within species, genus, and family of hornbills was measured using K2P methods (Table 5 and 6$)$. Average genetic distance within species was ranged from $0.002(0.2 \%)$ to $0.008(0.8 \%)$, within genus $0.045(4.5 \%)$, and within family 0.046 (4.6\%) (Table $5)$. Genetic distance distinguishing within species were lower than those learnt from previous studies (Yoo et al. 2006; Astuti and Sulandari 2010; Huang and $\mathrm{Tu}$ 2016); yet, it remains the same on genus and 


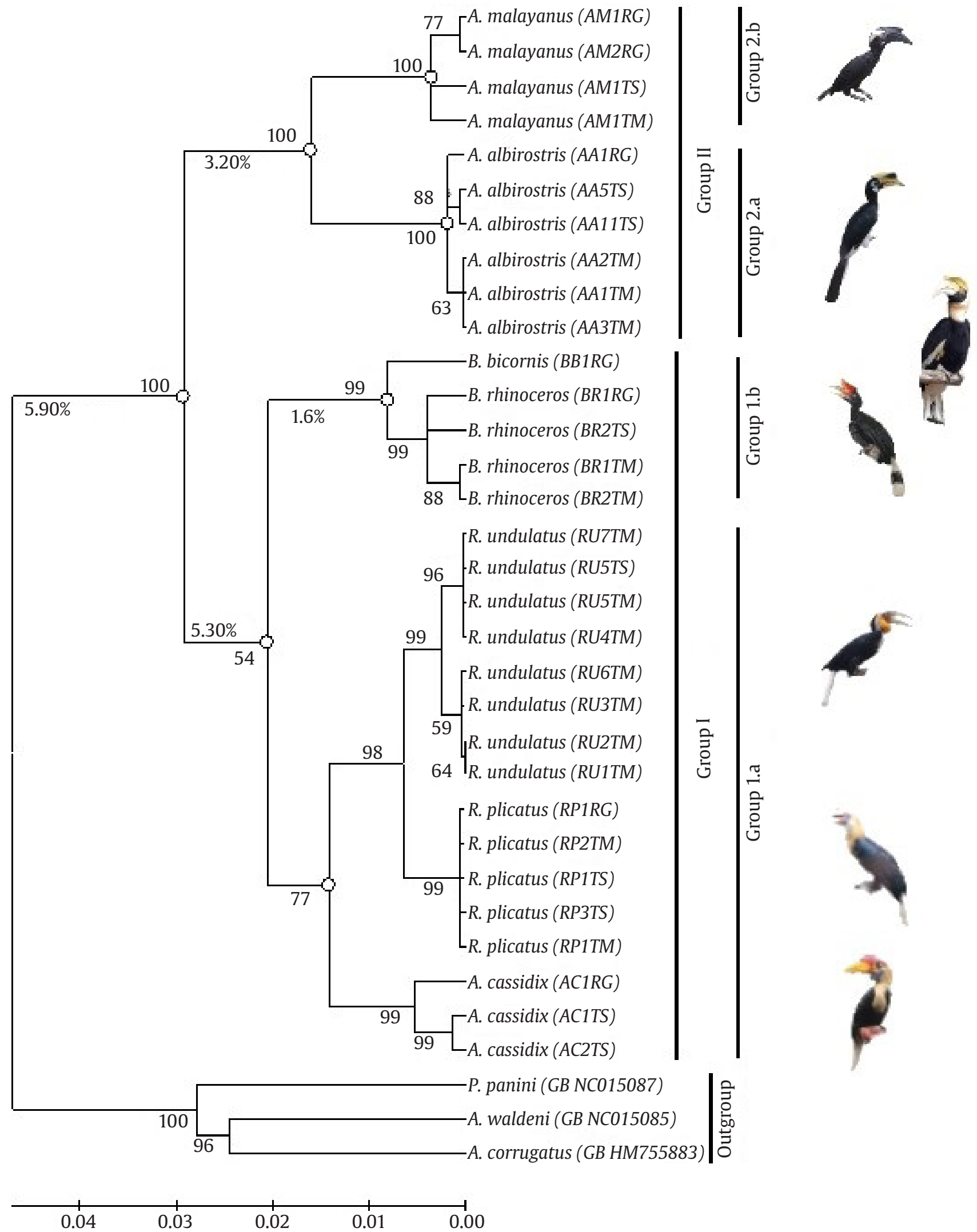

Figure 1. Neighbor-joining (NJ) phylogenetic tree of hornbills based on partial sequence of COI gene with 746 bp length 
family level, especially to what observed in Hebert et al. (2004), Kerr et al. (2007), Astuti and Sulandari (2010), and Huang and Tu (2016). Genetic distance within species is usually less than $1 \%$ and infrequently reaching more than $2 \%$ (Waugh 2007), as seen in average genetic distance within species of Korean birds and Phasianidae as much as 0.3\% (Yoo et al. 2006; Cai et al. 2010), in Neotropical birds which ranged between 0 to 13.7\% (Tavares et al. 2011) and in parrots that ranged from 0.1 to $0.7 \%$ (Gonçalves et al. 2015).

The mean genetic distance within genus appears to vary (Table 6). Interspecific genetic distance within two genera (Rhyticeros and Buceros) was lower than the threshold for species separation (> 3.0\%). According to Efe et al. (2009) the difference in COI gene among species within Laridae (Sternini) ranged from 0.25 to $10.51 \%$. In addition, Rhyticeros undulatus and $R$. plicatus have some morphological similarities. Variations in their body color are found in the head, neck, and neck pouch. The pair of Buceros rhinoceros and B. bicornis also bear some resemblances, where both having identical shape of casque, similar color on neck and wings (MacKinnon et al. 2010; Poonswad et al. 2013; Eaton et al. 2016). In contrast, genetic distance between Anthracoceros malayanus and A. albirostris was 0.032 (3.2\%), as the interspecific COI sequence differences on Anthracoceros genus is above the threshold. The genetic distance to accurately identify species should be above 5\% (Waugh 2007). Huang and $\mathrm{Tu}$ (2016) reported the mean divergence of the COI gene within genus in Ardeidae was $13.08 \%$; $8.2 \%$ within genera of Korean birds (Yoo et al. 2006); 4.8-15.6\% within Thamnophilidae (Passeriformes)(Vilaça et al. 2006); 5.35\% on Phasianidae (Cai et al. 2010); 7.95\% on Scandinavian birds (Johnsen et al. 2010); and 9.52\% on Green Bee-eater (Merops orientalis) (Arif et al. 2011). Genetic distance within Bucerotidae family 0.046 (4.6\%), which is lower than what found in previous studies (Table 6). Yoo et al. (2006) found mean genetic distance within the Korean bird families was $13.8 \%$, while on Phutananidae was 15.63\% (Cai et al. 2010).

Our phylogenetic tree delineated the segregation of genus Anthracoceros from other genera tested in this study. The seven species of Indonesian hornbill clustered accordingly in phylogeny tree. This study indicated that phylogenetic tree reconstructed from COI genes is deemed to be able to separate interspecies (within genus) and inter genera (within family) of hornbills. It also suggested that the kinship test based on COI gene sequence has considerable accuracy. Branches in phylogenetic trees represent the relationships between units, describing hereditary relationships back to the ancestors, while the length of branches describes the number of evolutionary changes occurred between two nodes (Graur and Li 2000). Sequence diversity of COI genes (648 bp) retains potential use for identification on species level, as well as having function as DNA barcode (Hebert et al. 2003a, b; Hebert and Gregory 2005). DNA barcoding based on COI has been successful in species determination and phylogeny across animal species (Huang and Tu 2016), as well proven satisfied on animal identification (Hajibabaei et al. 2006).

\section{Acknowledgements}

We would like to thank to the Directorate General of Higher Education, Ministry of Research, Technology, and Higher Education of the Republic Indonesia for funding this research through doctoral dissertation and applied research of higher education research grant on 2017 (contract number 896/UN30.15/LT/2017 and 011/SP2H/LT/DRPM/VIII/2017). This research has been approved by Director General of Natural Resources Conservation and Ecosystem, Ministry of Environmental and Forestry, Number: SK.399/KSDAE/ SET/KSA.2/11/2016. We also thank to the animal ethics commission of the Bogor Agricultural University for ethic approval. We grateful to LIPI and BKSDA Jakarta for the SATS-DN recommendation and sampling permit in TMII and TMR. We also thank to M. Nazri Janra who helped us to improve the English of this manuscript. The authors are grateful to TMII, TMR, TSI staff, and our laboratory collogues for their assistance in this study.

\section{Conflict of Interest}

There is no conflict of interest among authors.

\section{References}

Arif IA et al. 2011. Cytochrome c oxidase subunit I barcoding of the green bee-eater (Merops orientalis). Genetics and Molecular Research 10:3992-3998.

Astuti D, Sulandari S. 2010. The DNA sequence performance of COI gene in White Cockatoos (Cacatua, Psittacifrmes). Treubia 37:1-14.

Avise JC. 1994. Molecular Markers, Natural History and Evolution. New York: Chapman and Hall. pp. 511.

Balasubramanian P et al. 2011. Avian frugivory and seed dispersal of Indian Sandalwood Santalum album in Tamil Nadu, India. Journal of Threatened Taxa 3:17751777. 
Brown WM et al. 1982. Mitochondrial DNA sequences of primates: tempo and mode of evolution. Journal of Molecular Evolution 18:225-239.

Cai $Y$ et al. 2010. DNA barcoding on subsets of three families in Aves. Mitochondrial DNA 21:132-137.

Coates BJ et al. 2000. Panduan Lapangan Burung-Burung di Kawasan Wallacea: Sulawesi, Maluku, dan Nusa Tenggara. Birdlife International-Indonesia Programme and Dove Publications. Indonesia.

Eaton JA et al. 2016. Birds of the Indonesian Archipelago: Greater Sundas and Wallacea. Barcelona: Lynx edicions.

Efe MA et al. 2009. Multigene phylogeny and DNA barcoding indicate that the Sandwich tern complex (Thalasseus sandvicensis, Laridae, Sternini) comprises two species. Molecular Phylogenetics and Evolution 52:263-267.

Gonçalves PFM et al. 2015. DNA barcoding identifies illegal parrot trade. Journal of Heredity 106:560-564.

Gonzales JCT et al. 2013. A comprehensive molecular phylogeny for the hornbills (Aves:Bucerotidae). Molecular Phylogenetics and Evolution 67:468-483.

Graur D, Li WH. 2000. Fundamental of Molecular Evolution Second Edition. Sunderland: Sinauer Associates Inc. pp. 481.

Hajibabaei M et al. 2006. A minimalist barcode can identify a specimen whose DNA is degraded. Molecular Ecology Notes 6:959-964.

Hajibabaei M et al. 2007. DNA barcoding: how it complements taxonomy, molecular phylogenetics and population genetics. Trends in Genetics 23:167-172.

Hall TA. 1999. BioEdit: a user-friendly biological sequence alignment editor and analysis program for Windows 95/98/NT. Nucl Acids Symp Ser 41:95-98.

Hebert PDN et al. 2003a. Biological identifications through DNA barcodes. Proc R Soc Lond B 270:313-321.

Hebert PDN et al. 2003b. Barcoding animal life: cytochrome c oxidase subunit 1 divergences among closely related species. Proc R Soc Lond B 270:S96-S99.

Hebert PDN et al. 2004. Identification of birds through DNA barcodes. PLoS Biol 2:e312. https://doi.org/10.1371/ journal.pbio.0020312

Hebert PDN, Gregory TR. 2005. The promise of DNA barcoding for taxonomy. Syst Biol 54:852-859.

Huang Z, Tu F. 2016. DNA barcoding and phylogeny of Calidris and Tringa (Aves: Scolopacidae). Mitochondrial DNA 28:616-619. http://dx.doi.org/ 10.3109/ 24701394.2016.1155121.1-4.

Imtiaz A et al. 2017. Review: Progress and potential of DNA barcoding for species identification of fish species. Biodiversitas 18:1394-1405.

Johnsen A et al. 2010. DNA barcoding of Scandinavian birds reveals divergent lineages in trans-Atlantic species. J Ornithol 151:565-578.

Kerr KCR et al. 2007. Comprehensive DNA barcode coverage of North American birds. Molecular Ecology Notes 7:535-543.

Kimura M. 1980. A simple method for estimating evolutionary rates of base substitutions through comparative studies of nucleotide sequences. J Mol Evol 16:111120.

Kinnaird MF. 1998. Evidence for effective seed dispersal by the Sulawesi Red-Knobbed Hornbill Aceros cassidix. Biotropica 30:50-55.

Kitamura Set al. 2008. Aggregated seed dispersal by wreathed hornbills at a roost site in a moist evergreen forest of Thailand. Ecological Research 23:943-952.
MacKinnon J et al. 1998. Burung-Burung di Sumatera, Jawa, Bali dan Kalimantan (termasuk Sabah, Sarawak dan Brunei Darussalam). Bogor: Puslitbang Biologi LIPI.

MacKinnon J et al. 2010. Burung-Burung di Sumatera, Jawa, Bali dan Kalimantan (termasuk Sabah, Sarawak dan Brunei Darussalam). Bogor: Puslitbang Biologi LIPI.

Pacheco MA et al. 2011. Evolution of modern birds revealed by mitogenomics: timing the radiation and origin of major orders. Mol Biol Evol 28:1927-1942.

Palumbi SR, Cipriano F. 1998. Species identification using genetic tools: the value of nuclear and mitochondrial gene sequences in Whale conservation. The Journal of Heredity 89:459-464.

Poonswad P et al. 1998. Some aspects of food and feeding ecology of sympatric hornbill species in Khao Yai National Park, Thailand. In: Poonswad P. (Ed.), The Asian Hornbills: Ecology and Conservation. Biotec, NSTDA. pp. 137-157.

Poonswad P et al. 2013. Hornbills of the World. Thailand: Draco publishing and distribution.

Prehadi et al. 2015. DNA barcoding and phylogenetic reconstruction of shark species landed in Muncar fisheries landing site in comparison with Southern Java fishing port. Biodiversitas 16:55-61.

Sambrook J et al. 1989. Molecular Cloning: a Laboratory Manual. New York: Cold Spring Harbour Laboratory Press.

Sammler S et al. 2011. Full mitochondrial genome sequences of two endemic Philippine hornbill species (Aves: Bucerotidae) provide evidence for pervasive mitochondrial DNA recombination. BMC Genomics 12:35. doi: $10.1186 / 1471-2164-12-35$

Seutin G et al. 1991. Preservation of avian blood and tissue samples for DNA analysis. Can J Zool 69:82-90.

Solihin DD. 1994. Peran DNA mitokondria (mtDNA) dalam studi keragaman genetik dan biologi populasi pada hewan. Hayati 1:1-4.

Sukmantoro W et al. 2007. Daftar Burung Indonesia no. 2. Bogor: IdOU.

Sutarno. 2003. Genetic diversity: detection of gene variation at the DNA level and utilization of gene markers on locating QTLs. Biodiversitas 4:58-62.

Tamura Ket al. 2013. Mega6: molecular evolutionary genetics analysis version 6.0. Mol Biol Evol 30:2725-2729.

Tavares ES et al. 2011. DNA barcode detects high genetic structure within neotropical bird species. PLOS ONE 6:e28543.

Vilaça ST et al. 2006. DNA-based identification applied to Thamnophilidae (Passeriformes) species: the first barcodes of Neotropical birds. Revista Brasileira de Ornitologia 14:7-13.

Viseshakul N et al. 2011. A phylogeny of frugivorous hornbills linked to the evolution of Indian plants within Asian rainforests. Journal of Evolutionary Biology 24:15331545.

Waugh J. 2007. DNA barcoding in animal species: progress, potential and pitfalls. BioEssays 29:188-197.

Yoo HS et al. 2006. DNA barcoding Korean birds. Mol Cells 22:323-327.

Zhou X et al. 2015. Complete mitochondrial genomes render the Night Heron genus Gorsachius non-monophyletic. J Ornithol 157:505-513. DOI 10.1007/s10336-0151297-z. 